\title{
Residual Effects of Phosphorus and High Rates of Nitrogen on Shortgrass Rangeland
}

\author{
FRANK RAUZI
}

\begin{abstract}
Plots on shortgrass rangeland in southeastern Wyoming that received high rates of nitrogen applied once in 1970 or four times (1970 through 1973) were split, and phosphorus $\left(P_{2} 0_{5}\right)$ at $56 \mathrm{~kg} / \mathrm{ha}$ was applied to half of each plot in the spring of 1975 . Over a 3 -year period (1975-77), average total herbage yields and yields of individual species were generally less for all treatments during the residual period (1975-77) than during the years of fertilization (1970 through 1973). Blue grama density decreased during the nitrogen fertilization period but increased during the 3 residual years, so that in 1977 density was almost the same as that in 1970. Western wheatgrass increased in all nitrogen treatments and generally remained high during the $1975-1977$ period. During this residual period, previous nitrogen fertilization tended to increase the yield of western wheatgrass, forbs, and total herbage and decrease that of blue grama and dryland sedges. The application of phosphorus did not influence herbage yields or crude protein content of western wheatgrass or blue grama. Phosphorus also did not influence concentrations of calcium, magnesium and potassium in blue grama.
\end{abstract}

During the past 30 years, many studies on rangeland fertilization have been conducted in the Great Plains. Most early studies involved a single application of less than $112 \mathrm{~kg} / \mathrm{ha}$ of nitrogen (N). Also, many of these studies were of short duration, 1 to 3 years.

McIlvain and Shoop (1970) showed that applications of $39 \mathrm{~kg}$ $\mathrm{N} /$ ha increased forage production about $40 \%$ and beef production about $31 \%$ over the control in a 4-year grazing trial at Woodward, Okla. Westin et al. (1955) found residual N affected forage production for 3 years after the application of 22,45 , and $90 \mathrm{~kg} \mathrm{~N} / \mathrm{ha}$ on heavily and lightly grazed pastures in South Dakota. Also, the $90 \mathrm{~kg} \mathrm{~N} / \mathrm{ha}$ application once in 3 years resulted in more hay per unit of $\mathrm{N}$ than did $90 \mathrm{~kg}$ of $\mathrm{N}$ applied once each year for 3 years.

Rogler and Lorenz (1957) applied 0, 34, and $101 \mathrm{~kg} \mathrm{~N} \cdot \mathrm{ha}^{-1}$. $\mathrm{yr}^{-1}$ to moderately and heavily grazed pastures for 6 years at Mandan, N. Dak. The $101 \mathrm{~kg} \mathrm{~N} / \mathrm{ha}$ treatment produced an average of $2,543 \mathrm{~kg} / \mathrm{ha}$ air-dry forage from the heavily grazed pastures; whereas, the 0 and $34 \mathrm{~kg} / \mathrm{ha} \mathrm{N}$ rates produced an average of 834 and $1,485 \mathrm{~kg} /$ ha air-dry forage, respectively. Dwyer (1971) applied 0,45 and $67 \mathrm{~kg} \mathrm{~N} \cdot \mathrm{ha}^{-1} \cdot \mathrm{yr}^{-1}$ for 6 years to blue grama (Bouteloua gracilis) range in southcentral New Mexico and found grass production was significantly increased over the control. Dwyer found that production of forbs was not significantly affected by $\mathrm{N}$ fertilization.

High $\mathrm{N}$ fertilization rates (over $112 \mathrm{~kg} / \mathrm{ha}$ ) were first investigated by Johnston et al. (1967) and Choriki et al. (1968),

\footnotetext{
The author is soil scientist, U.S. Department of Agriculture, Science and Education Administration-Agricultural Research.

This research was done in cooperation with the University of Wyoming Agricultural Experiment Station. Approved by the Director as Journal Articlc No. 984 Manuscript received September 20, 1978.
}

who found that 672 to $1,120 \mathrm{~kg} \mathrm{~N} / \mathrm{ha}$ drastically affected botanical composition. Annual forbs increased and perennial grasses decreased in these treatments. In Oregon, Baldwin et al. (1974) found a variety of forbs in all plots, but they did not respond noticeably to $\mathrm{N}$ rates of $0,333,665$, and $1,331 \mathrm{~kg} / \mathrm{ha}$. Wight (1976) concluded that high $\mathrm{N}$ rates $(112$ to $1,008 \mathrm{~kg} / \mathrm{ha})$ on an upland range site in Montana significantly affected species composition: western wheatgrass (Agropyron smithii) increased and accounted for most of the forage yield.

Power (1970) found that $538 \mathrm{~kg} \mathrm{~N} / \mathrm{ha}$ immediately established a large pool of soil $\mathrm{NO}_{3}-\mathrm{N}$ for plant use, and fertilizer that was not used in one season was carried over to the next in mineral form. In all instances where fertilizer $\mathrm{N}$ was added, about $353 \mathrm{~kg} \mathrm{~N} / \mathrm{ha}$ was immobilized in various compartments of the $\mathrm{N}$ cycle (Power 1972). He also stated that $\mathrm{N}$ immobilizing capacity of a given system may vary with soil texture, vegetation, and other parameters. In southeast Wyoming, Rauzi (1978) found that blue grama and buffalograss (Buchloe dactyloides) decreased and western wheatgrass increased on plots that received $672 \mathrm{~kg} \mathrm{~N} / \mathrm{ha}$ at one time or 168 $\mathrm{kg} \mathrm{N} / \mathrm{ha}$ each year for 4 years.

This paper reports on results of an additional 3 years of data to determine effects of phosphorus and residual high $\mathbf{N}$ applications on a shortgrass rangeland in southeastern Wyoming.

\section{Methods}

The study area was at the Archer Substation about $17 \mathrm{~km}$ east of Cheyenne, elevation about $1,859 \mathrm{~m}$. Dominant species were blue grama, buffalograss and western wheatgrass. Soil on the Experimental area was Archerson fine sandy loam, a member of the mixed, mesic family of Aridic Argiustols. Archerson soils are on nearly level to gently sloping fans and terraces and are of granitic origin.

In March 1970 , plots $3 \times 15 \mathrm{~m}$ were established on native shortgrass rangeland. The experiment was a randomized complete block with four fertilizer treatments and three replications. Ammonium nitrate was surface broadcast in March 1970, at rates of 0 , 168 , and $672 \mathrm{~kg} \mathrm{~N} / \mathrm{ha}$. A fourth treatment of $168 \mathrm{~kg} \mathrm{~N} / \mathrm{ha}$ was applied annually in March for 4 years (1970-1973). In March 1975, main plots were split and $56 \mathrm{~kg} \mathrm{P}_{2} \mathrm{O}_{5} / \mathrm{ha}$ was hand applied to one half of each plot.

Each spring (1975 through 1977) three subplots $0.18 \mathrm{~m}^{2}$ wcre randomly located on each plot, and the previous year's vegetation was removed before plant growth started. Herbage from these same subplots was harvested at ground level in mid August and separated by major species. Annual grasses, forbs, and Sandberg bluegrass matured before harvest and a large part of their production was lost. After subplots were harvested, the experimental area was grazed by sheep.

Air dry herbage yields were determined for the major grass species, dryland sedges, forbs, and total herbage. Botanical composition was determined by weight of the major species. All data were analyzed by split plot analysis procedure. Duncan's multiple range test for significance was used to separate means at the $5 \%$ lcvel of probability.

Blue grama and western wheatgrass plant material was ground in a Wiley mill to pass through a 40-mesh screen. These samples were dry 
Table 1. Annual, April through September, and April, May and June precipitation (centimeters) for 1975-77, and the 57-year (1921-77) average at the Archer Substation, Cheyenne, Wyo.

\begin{tabular}{|c|c|c|c|c|c|c|}
\hline Year & Annual & $\begin{array}{c}\text { April } \\
\text { through } \\
\text { September }\end{array}$ & April & May & June & $\begin{array}{c}\text { April } \\
\text { through } \\
\text { June }\end{array}$ \\
\hline 1975 & 28.9 & 20.5 & 2.6 & 7.1 & 4.0 & 13.7 \\
\hline 1976 & 28.9 & 23.8 & 4.2 & 4.2 & 1.6 & 10.0 \\
\hline 1977 & 41.7 & 36.1 & 5.3 & 10.4 & 1.9 & 17.6 \\
\hline \multicolumn{7}{|l|}{ Average } \\
\hline $1921-77$ & 37.1 & 28.8 & 3.8 & 6.5 & 6.2 & 16.5 \\
\hline $1975-77$ & 33.2 & 26.8 & 4.0 & 7.2 & 2.5 & 13.8 \\
\hline
\end{tabular}

ashed, and calcium (ca), magnesium $(\mathrm{Mg})$ and potassium $(\mathrm{K})$ were determined by atomic absorption spectrophotometry. Phosphorus (P) was determined by the Vanadomolybdophosphoric yellow color method in a nitric acid system (Jackson 1958). Total plant $\mathrm{N}$ was determined by the Kjeldahl method and crude protein was calculated $(\% \mathrm{~N} \times 6.25)$ (Agricultural Biochemistry Division, University of Wyoming). Soil from the 0 to $15-\mathrm{cm}$ soil depth was sampled in 1977 from all treatments and analyzed for available $\mathrm{P} \mathrm{NaHCO}_{3}$ extraction method (Olsen et al. 1954).

\section{Results and Discussion}

Precipitation during June of 1975 through 1977 was considerably below the long-time average, and annual precipitation in 1975 and 1976 was below the $37.1 \mathrm{~cm}$ long-term annual average (Table 1). Precipitation in 2 out of the 3 years was above average for April and May. Thus, herbage yields were influenced by the amount and distribution of precipitation.

The $56 \mathrm{~kg} \mathrm{P}_{2} \mathrm{O}_{5} /$ ha treatment did not influence total herbage yield or yields of individual species. For all species, except forbs from the control and plots receiving $168 \mathrm{~kg} \mathrm{~N} / \mathrm{ha}$ each year for 4 years, yields were lower than respective yields for the 1970-1974 period (Table 2). Western wheatgrass yields were $29 \%$ less for the control and $61 \%$ less for plots that received one appliction $672 \mathrm{~kg} \mathrm{~N} / \mathrm{ha}$ that the average yields for the 1970-1974 period. Blue grama yiclds were $28 \%$ less on the control and $57 \%$ less on plots that received $168 \mathrm{~kg} \mathrm{~N} / \mathrm{ha}$ each year for 4 years than for the 1970-1974 average. Dryland sedges made up a small part of the overall yields, but their yields also decreased on all treatments as compared with the previous 5-year average. Total herbage yields were less on all treatments for 1975 to 1977 as compared with the 1970 to 1974 average. Total herbage yields decreased $22 \%$ on the control and $53 \%$ on the plots that received $672 \mathrm{~kg} \mathrm{~N} / \mathrm{ha}$ once compared to the previous 5-year average.

Much bare ground remained on the high N plots, but density of blue grama increased. Late July rains in 1977 probably increased the amount of blue grama on these plots. A trace of buffalograss was found on the high $\mathrm{N}$ plots in late summer of 1977.

Table 2. Yields (kg/ha) of western wheatgrass, blue grama, dryland sedges, forbs and total herbage from fertilized and nonfertilized plots, Archer Substation, Cheyenne, Wyoming.

\begin{tabular}{|c|c|c|c|c|c|}
\hline Year & Control & $168 \mathrm{~kg} \mathrm{~N} \cdot \mathrm{ha}^{-1} \cdot \mathrm{yr}^{-1}$ & $\begin{array}{c}168 \mathrm{~kg} \mathrm{~N} \cdot \mathrm{ha}^{-1} \cdot \mathrm{yr}^{1} \\
1970-1974\end{array}$ & $168 \mathrm{~kg} \mathrm{~N} \cdot \mathrm{ha}^{-1} \cdot \mathrm{yr}^{-1}$ & $\begin{array}{r}\text { Year } \\
\text { Mean }\end{array}$ \\
\hline \multicolumn{6}{|c|}{ Western wheatgrass } \\
\hline $\begin{array}{r}1970-74 \\
75 \\
76 \\
77\end{array}$ & $\begin{array}{l}82^{a 1} \\
59 \\
52 \\
62\end{array}$ & $\begin{array}{r}203^{y} \\
140 \\
106 \\
72\end{array}$ & $\begin{array}{l}196^{y} \\
206 \\
140 \\
138\end{array}$ & $\begin{array}{r}290^{x} \\
141 \\
91 \\
105\end{array}$ & $\begin{array}{r}137^{a} \\
97^{a} \\
94^{a}\end{array}$ \\
\hline Mean 1975-77 & $58^{b}$ & $106^{a b}$ & $161^{a}$ & $112^{a b}$ & 110 \\
\hline \multicolumn{6}{|c|}{ Blue grama } \\
\hline $\begin{array}{r}1970-74 \\
75 \\
76 \\
77\end{array}$ & $\begin{array}{l}383^{y} \\
155 \\
239 \\
437\end{array}$ & $\begin{array}{l}510^{x} \\
224 \\
277 \\
455\end{array}$ & $\begin{array}{l}502^{x} \\
156 \\
202 \\
295\end{array}$ & $\begin{array}{l}477^{x} \\
165 \\
190 \\
324\end{array}$ & $\begin{array}{l}175^{c} \\
226^{b} \\
377^{d}\end{array}$ \\
\hline Mean 1975-77 & $277^{a}$ & $319^{a}$ & $218^{b}$ & $226^{\circ}$ & \\
\hline \multicolumn{6}{|c|}{ Dryland sedges } \\
\hline $\begin{array}{r}1970-74 \\
75 \\
76 \\
77 \\
\text { Mean } 1975-77\end{array}$ & $\begin{array}{l}77^{x} \\
64 \\
85 \\
63 \\
71^{a}\end{array}$ & $\begin{array}{l}114^{x} \\
52 \\
56 \\
59 \\
56^{a}\end{array}$ & $\begin{array}{c}105^{x} \\
50 \\
47 \\
48 \\
48^{a}\end{array}$ & $\begin{array}{l}103^{x} \\
65 \\
50 \\
39 \\
51^{a}\end{array}$ & $\begin{array}{l}57^{a} \\
59^{a} \\
53^{a}\end{array}$ \\
\hline \multicolumn{6}{|c|}{ Forbs } \\
\hline $\begin{array}{r}1970-74 \\
75 \\
76 \\
77\end{array}$ & $\begin{array}{c}20^{z} \\
18 \\
130 \\
29\end{array}$ & $\begin{array}{c}78^{z} \\
17 \\
156 \\
16\end{array}$ & $\begin{array}{l}290^{y} \\
174 \\
734 \\
15\end{array}$ & $\begin{array}{l}465^{x} \\
217 \\
570 \\
24\end{array}$ & $\begin{array}{r}106^{b} \\
398^{a} \\
20^{c}\end{array}$ \\
\hline Mean 1975-77 & $59^{c}$ & $63^{c}$ & $308^{a}$ & $270^{b}$ & \\
\hline \multicolumn{6}{|c|}{ Total herbage } \\
\hline $\begin{array}{r}1970-74 \\
75 \\
76 \\
77\end{array}$ & $\begin{array}{l}724^{y} \\
429 \\
576 \\
679\end{array}$ & $\begin{array}{c}1105^{x} \\
500 \\
629 \\
662\end{array}$ & $\begin{array}{c}1229^{x y} \\
588 \\
1124 \\
503\end{array}$ & $\begin{array}{c}1399^{x} \\
580 \\
903 \\
494\end{array}$ & $\begin{array}{l}524^{b} \\
808^{a} \\
585^{b}\end{array}$ \\
\hline Mean & $561^{c}$ & $597^{b c}$ & $738^{a}$ & $659^{a b}$ & \\
\hline
\end{tabular}

\footnotetext{
${ }^{1}$ Means among treatments and years with the same letters are not significantly different at the $5 \%$ level.
} 
The dominant annual forb on these plots from 1975 to 1977 were slimleaf goosefoot (Chenopodium leptophyllum). Because of the amount and distribution of precipitation, growth was limited for this species all 3 years. However, in 1976, slimleaf goosefoot was abundant particularly on high N plots. During 1977, forb yields were of minor importance on all treatments, but slimleaf goosefoot and scarlet globemallow (Sphaeralcea coccinea) were the dominant forbs.

\section{Composition}

Vegetative composition was determined by weighing the separated air-dried herbage harvested from subplots. During the 8-year period (1970-1977), the vegetative composition of the plots was influenced by $\mathrm{N}$ treatment and prevailing weather (Fig. 1). Weather, particularly the amount and distribution of precipitation during the growing season, influenced the vegetative composition more during the last 3 years of the study (1975-1977) than did previous $\mathrm{N}$ treatments.

Between 1974 and 1977, western wheatgrass decreased on all treatments (Fig. 1). The control and plots treated once with 168 $\mathrm{kg} \mathrm{N} / \mathrm{ha}$ had slightly less western wheatgrass in the composition at the end of the study than at the beginning. Whereas, western wheatgrass percentage generally increased for the other two treatments.

During the first 5-years of the study, percentage composition of blue grama decreased for all treatments (Fig. 1). However, blue grama density increased enough in later years so that by the end of the study its density was about the same as that in 1970. Blue grama density increased 20 to $30 \%$ between 1976 and 1977 on all treatments probably because of a $14.81 \mathrm{~cm}$ of rainfall in late July, 1976.

Forbs were of minor importance on the control and plots treated once with $168 \mathrm{~kg} \mathrm{~N} / \mathrm{ha}$ (Fig. 1). The plots treated with $672 \mathrm{~kg} \mathrm{~N} / \mathrm{ha}$ once and those treated with $168 \mathrm{~kg} \mathrm{~N} / \mathrm{ha}$ each year for 4 years had an abundance of forbs, consisting mostly of slimleaf goosefoot and field pennycress (Thlaspi arvense) in all years except 1977. In 1977, forbs were not important on all treatments.

The amounts of dryland sedges varied slightly among years regardless of treatment. Plots treated with $168 \mathrm{~N} \mathrm{~kg} / \mathrm{ha}$ each year for 4 years had the least dryland sedges at the end of the study period.

\section{Crude Protein and Mineral Concentration}

Phosphorus applied in the spring of 1975, did not influence the crude protein content, $\mathrm{Ca}, \mathrm{Mg}$, or the $\mathrm{K}$ concentrations in herbage of blue grama and western wheatgrass.

Average crude protein content of blue grama fertilized each ycar for 4 years (1970-1973) with $168 \mathrm{~kg} \mathrm{~N} / \mathrm{ha}$ of fertilized once in 1970 with $672 \mathrm{~kg} \mathrm{~N} / \mathrm{ha}$ was significantly greater than the
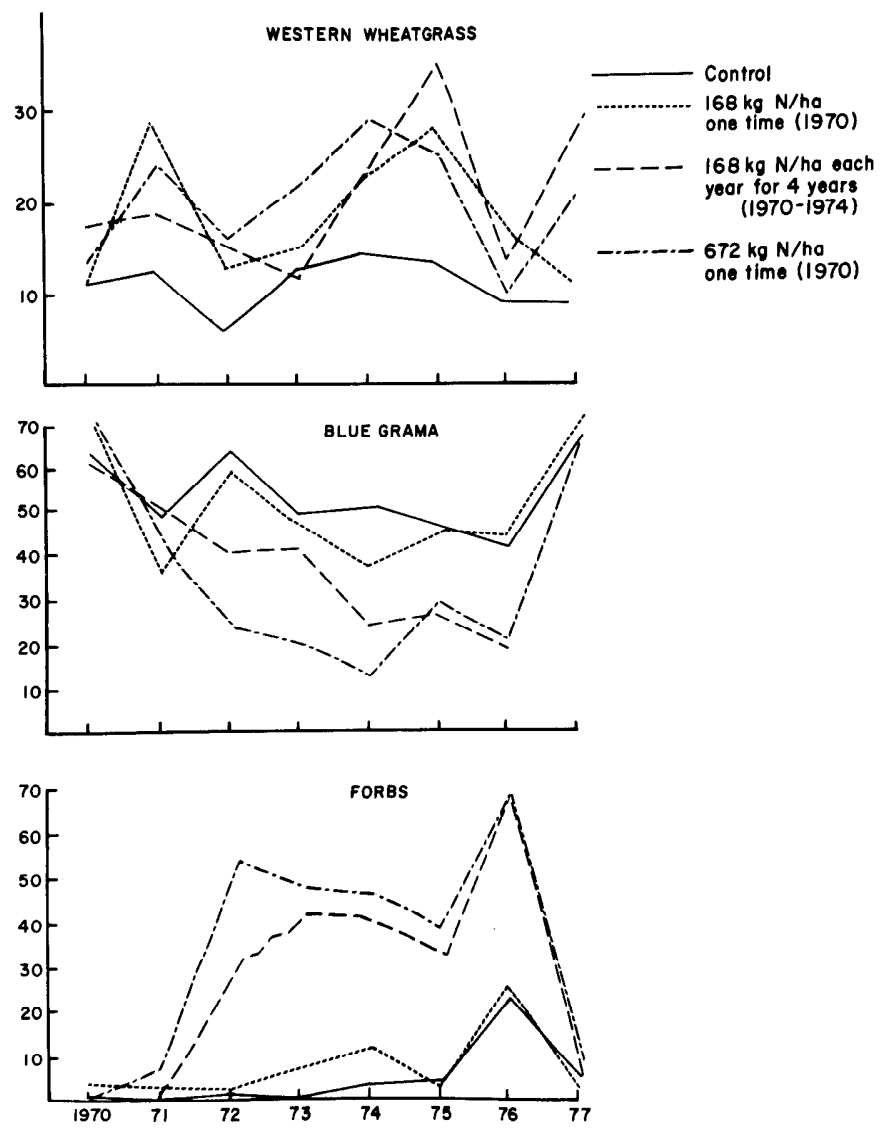

Fig. 1. Percentage composition by weight over an 8-year period of a shortgrass rangeland fertilized with 0,168 , and $672 \mathrm{~kg} \mathrm{~N} / \mathrm{ha}$ one time and $168 \mathrm{~kg} \mathrm{~N}$. $h a^{-1} \cdot y r^{-1}$ for 4 years.

control during the last 3 years (1975-77) (Table 3). In 1977, mean crude protein content was similar in blue grama fertilized each year for 4 years with $168 \mathrm{~kg} \mathrm{~N} / \mathrm{ha}$ and fertilized once in 1970 with $672 \mathrm{~kg} / \mathrm{ha}$. During the 1975 to 1977 period, there was no significant difference in crude protein content of western wheatgrass among years or fertilizer treatments (Table 3). However, the mean crude protein content of fertilized western wheatgrass for 1975 to 1977 was significantly greater than that for the control. Crude protein content of blue grama and western wheatgrass at the time of harvest was more than adequate for livestock nutritional requirements (National Research Council 1975, 1976). Most of the growth made by blue grama resulted from late July and early August rains, whereas western wheatgrass made its limited growth earlier in the season.

Phosphorus concentration in blue grama at harvest (Table 4)

Table 3. Percentage crude protein for blue grama and western wheatgrass from fertilized and nonfertilized plots, Archer Substation, Cheyenne, Wyoming.

\begin{tabular}{|c|c|c|c|c|c|c|c|c|}
\hline \multirow[b]{2}{*}{ Year } & \multicolumn{4}{|c|}{ Blue grama } & \multicolumn{4}{|c|}{ Western wheatgrass } \\
\hline & Control & $168 \mathrm{~kg} \mathrm{~N} / \mathrm{ha}^{1}$ & $\begin{array}{l}168 \mathrm{~kg} \mathrm{~N} / \mathrm{ha} \\
(1970-74)\end{array}$ & $672 \mathrm{~kg} \mathrm{~N} / \mathrm{ha}^{1}$ & Control & $168 \mathrm{~kg} \mathrm{~N} / \mathrm{ha}^{1}$ & $\begin{array}{c}168 \mathrm{~kg} \mathrm{~N} / \mathrm{ha} \\
(1970-74)\end{array}$ & $672 \mathrm{~kg} \mathrm{~N} / \mathrm{ha}^{1}$ \\
\hline $1970-74^{2}$ & $8.3^{23}$ & $11.4^{y}$ & $14.4^{x}$ & $14.3^{x}$ & $7.6^{2}$ & $9.4^{y}$ & $12.1^{x}$ & $12.0^{x}$ \\
\hline 1975 & $12.5^{c}$ & $12.9^{b c}$ & $14.7^{a}$ & $13.7^{b}$ & $10.1^{a}$ & $11.8^{a}$ & $13.9^{a}$ & $13.1^{a}$ \\
\hline 1976 & $12.9^{b}$ & $13.3^{a b}$ & $14.0^{a}$ & $13.1^{b}$ & $13.0^{a}$ & $13.6^{a}$ & $13.3^{a}$ & $13.0^{a}$ \\
\hline 1977 & $13.6^{b}$ & $14.1^{b}$ & $15.1^{a}$ & $14.7^{a b}$ & $17.2^{a}$ & $18.0^{a}$ & $18.7^{a}$ & $18.1^{a}$ \\
\hline Mean & $13.0^{c}$ & $13.4^{b c}$ & $14.6^{a}$ & $13.8^{b}$ & $13.4^{c}$ & $14.5^{a b}$ & $15.3^{a}$ & $14.7^{a b}$ \\
\hline
\end{tabular}

${ }^{1}$ Fertilized once in the early spring of 1970.

2 Average from $1970-1974$ period.

${ }^{3}$ Means within rows among treatments and years with the same letters are not significantly different at the $5 \%$ level. 
Table 4. Percentage phosphorus, calcium, magnesium, and potassium in blue grama tissue from fertilized and nonfertilized plots, Archer Substation, Cheyenne, Wyo.

\begin{tabular}{|c|c|c|c|c|c|}
\hline \multirow[b]{2}{*}{$\begin{array}{l}\text { Year and } \\
\text { constituent }\end{array}$} & \multicolumn{4}{|c|}{ Blue grama } & \multirow[b]{2}{*}{ Mean } \\
\hline & Control & $\begin{array}{l}168 \mathrm{~kg} \\
\mathrm{~N} / \mathrm{ha}^{2}\end{array}$ & $\begin{array}{c}168 \mathrm{~kg} \\
\mathrm{~N} / \mathrm{ha} \\
(1970-1974)\end{array}$ & $\begin{array}{l}672 \mathrm{~kg} \\
\mathrm{~N} / \mathrm{ha}^{1}\end{array}$ & \\
\hline
\end{tabular}

\begin{tabular}{|c|c|c|c|c|c|}
\hline \multicolumn{6}{|l|}{ Phosphorus } \\
\hline 1975 & $.13^{a 2}$ & $.12^{a}$ & $.12^{a}$ & $.12^{a}$ & $.12^{b}$ \\
\hline 1976 & $.16^{a}$ & $.15^{a}$ & $.15^{a}$ & $.14^{a}$ & $.15^{a}$ \\
\hline 1977 & $.15^{a}$ & $.15^{a}$ & $.16^{a}$ & $.16^{a}$ & $.15^{a}$ \\
\hline Mean & $.14^{a}$ & $.14^{a}$ & $.14^{a}$ & $.14^{a}$ & \\
\hline \multicolumn{6}{|l|}{ Calcium } \\
\hline 1975 & $.45^{a}$ & $.44^{a}$ & $.52^{a}$ & $.46^{a}$ & $.47^{a}$ \\
\hline 1976 & $46^{a}$ & $.45^{a}$ & $.41^{a}$ & $.45^{a}$ & $.44^{a}$ \\
\hline 1977 & $.44^{a}$ & $.42^{a}$ & $.44^{a}$ & $.44^{a}$ & $.43^{a}$ \\
\hline Mean & $.45^{a}$ & $.44^{a}$ & $.46^{a}$ & $.45^{a}$ & \\
\hline \multicolumn{6}{|l|}{ Magnesium } \\
\hline 1975 & $.13^{a}$ & $.13^{a}$ & $.16^{a}$ & $.15^{a}$ & $.14^{a}$ \\
\hline 1976 & $.14^{a}$ & $.14^{a}$ & $.13^{a}$ & $.14^{a}$ & $.14^{a}$ \\
\hline 1977 & $.13^{a}$ & $.12^{a}$ & $.13^{a}$ & $.13^{a}$ & $.13^{a}$ \\
\hline Mean & $.13^{a}$ & $.13^{a}$ & $.14^{a}$ & $.14^{a}$ & \\
\hline \multicolumn{6}{|l|}{ Potassium } \\
\hline 1975 & $.98^{b}$ & $1.03^{\circ}$ & $1.24^{a}$ & $1.15^{a b}$ & $1.10^{a}$ \\
\hline 1976 & $.75^{c}$ & $.80^{b c}$ & $.95^{a}$ & $.87^{a}$ & $.84^{c}$ \\
\hline 1977 & $.89^{b}$ & $.96^{b}$ & $1.09^{a}$ & $.99^{a b}$ & $.98^{b}$ \\
\hline Mean & $.87^{c}$ & $.93^{b c}$ & $1.09^{a}$ & $1.00^{a}$ & \\
\hline
\end{tabular}

' Fertilized once in early spring, 1970.

${ }^{2}$ Means within rows among treatments and years with the same letters are not significantly different at the $5 \%$ level.

was deficient for adequate livestock nutrition. Phosphorus requirements for pregnant and lactating ewes range from 0.20 to $0.25 \%$ and 0.35 to $0.37 \%$, respectively, (National Research Council 1975). Phosphorus requirements for pregnant beef cows is $0.18 \%$ and for lactating cows is 0.25 to $0.37 \%$ (National Research Council 1976). Concentration of $P$ in herbage of blue grama was significantly higher in 1976 and 1977 than for the year of application (1975). The overall $P$ concentrations for the 3 -year period averaged $0.14 \%$ regardless of $\mathrm{N}$ treatment. The soil analysis at the end of the study indicated that all plots fertilized with $\mathrm{P}_{2} \mathrm{O}_{5}$ had significantly more available $\mathrm{P}$ than did plots not fertilized with $\mathrm{P}_{2} \mathrm{O}_{5}$.

The $\mathrm{Ca}$ concentrations in blue grama were more than adequate for livestock nutrition. Pregnant ewes require between 0.21 to $0.27 \% \mathrm{Ca}$ in their diet and lactating ewes require 48 to $52 \% \mathrm{Ca}$ (National Research Council 1975). Pregnant beef cows require $0.18 \% \mathrm{Ca}$ in their diet and lactating cows require 25 to 44\% Ca (National Research Council 1976). There was no significant difference among treatments in $\mathrm{Ca}$ concentrations in blue grama (Table 4 ). The overall $\mathrm{Ca}$ concentrations in blue grama for the 3 -year period averaged $0.45 \%$.

Magnesium content in bluc grama was more than adequate for sheep nutrition at harvest. The National Research Council $1975,1976)$ requirements are $0.06 \%$ for an adult ewe and $0.18 \%$ for a lactating beef cow and finishing beef cattle. The residual effect of $\mathrm{N}$ treatments did not influence the concentration of $\mathrm{Mg}$ in bluc grama (Table 4). $\mathrm{Mg}$ concentrations in blue grama averaged $0.13 \%$.

The residual effects of $\mathrm{N}$ treatments significantly influenced $\mathrm{K}$ concentrations in blue grama. Potassium content was higher in the blue grama herbage from plots that received $168 \mathrm{~kg} \mathrm{~N} / \mathrm{ha}$ each year for 4 years or $672 \mathrm{~kg} \mathrm{~N} / \mathrm{ha}$ in 1970 than that from the control or plots that received $168 \mathrm{~kg} \mathrm{~N} / \mathrm{ha}$ once (Table 4). The yearly mean of $\mathrm{K}$ concentrations in blue grama differed significantly. The K concentration was lowest in 1976 and highest in 1975 . Since the $\mathrm{K}$ requirement is $0.50 \%$ for sheep and 0.6 to $0.8 \%$ for growing and finishing steers (National Research Council 1975, 1976), $\mathrm{K}$ concentrations were more than adequate for all treatments.

\section{Conclusions}

Residual effects of high rates of nitrogen on shortgrass rangeland in southeastern Wyoming were still evident 8 years after application. Yields of western wheatgrass, blue grama, and forbs were significantly higher during the residual period (1975-77) from the plots treated with $168 \mathrm{~kg} \mathrm{~N} \cdot \mathrm{ha}^{-1} \cdot \mathrm{yr}^{-1}$ for 4 years and plots treated with $672 \mathrm{~kg} \mathrm{~N} / \mathrm{ha}$ once than from the control or the plots treated once with a single application of 168 $\mathrm{kg} \mathrm{N} / \mathrm{ha}$.

Average crude protein content of the western wheatgrass and blue grama were significantly greater from the plots treated with the high rates of $\mathrm{N}$ than from the control or the plots treated once with the single low $\mathrm{N}$ application.

A desirable change in species composition at the end of the study was the increase of western wheatgrass on the high $\mathrm{N}$ plots. Blue grama decreased in composition the first 5 years (1970-74) of the study on the high $N$ plots, but by the 8th year its density was about he same as it was at the start of the study.

Over the 8-year period (1970-77) the plots treated with $168 \mathrm{~kg}$ $\mathrm{N} /$ ha each year for 4 years and the plots treated with $672 \mathrm{~kg} \mathrm{~N} / \mathrm{ha}$ once produced 3,052 and $3,668 \mathrm{~kg} / \mathrm{ha}$ more total herbage, respectively, than did the control. Thus, the total herbage increase over the 8-year period on the two high $\mathrm{N}$ treatments was not economical since it only represented 4.5 and $5.5 \mathrm{~kg} / \mathrm{ha}$ increase in total herbage for each $\mathrm{kg} \mathrm{N}$ applicd, respectively.

The application of $P$ during the residual period (1975-77) was not beneficial as it did not increase the yields or crude protein of the western wheatgrass or blue grama. Phosphorus also did not influence the concentrations of $\mathrm{Ca}, \mathrm{Mg}$, or $\mathrm{K}$ content of the blue grama.

\section{Literature Cited}

Baldwin, Donald M., Newton W. Hawkinson, and E. William Anderson. 1974. Highrate fertilization of native rangeland in Oregon. J. Range Manage. 27:214-216.

Choriki, R.I., D.E. Ryerson, A.L. Dubbs, and Jack Taylor. 1968. Rates and spacing of fertilizer on improvement of yield, species and nutrients absorption on mixed prairie vegetation. Agron. Abstr. Amer. Soc. Agron. p. 100.

Dwyer, Don D. 1971. Nitrogen fertilization of blue grama rangeland in the foothills of South-Central New Mexico, New Mexico State Univ. Agr. Exp. Sta. Bull. 585.8 p.

Jackson, M.L. 1958. Soil Chemical Analysis. Prentice Hall. Englewood Cliffs, N.J. p. 151-153.

Johnston, A., S. Smoliak, A.D. Smith, and L.E. Lutwick. 1967. Improvement of Southeastern Alberta range with fertilizer. Can. J. Plant Sci. 47: 671-678.

McIlvain, E.H., and M.C. Shoop. 1970. Proc. of the first weeping lovegrass Symp. Sponsored by Agr. Div., The Samuel Roberts Nobel Foundation, Inc., Ardmore, Okla.

National Academy of Science and National Research Council. 1975. Nutrient requirements of sheep. National Research Council. Washington, D.C. p. 72 .

National Academy of Science and National Research Council. 1976. Nutritional requirements of domestic animals No. 4. Fifth revised edition. Nutrient requirements of beef cattle. National Research Council. Washington, D.C. p. 56.

Olsen, Sterling R., C.V. Cole, Frank S. Watanabe, and L.A. Dean. 1954. 
Estimation of available phosphorus in soils by extraction with sodium bicarbonate. U.S. Dep. Agr. Circ. No. 939.

Power, J.F. 1970. Leaching of nitrate nitrogen under dryland agriculture in the Northern Great Plains. In: Relationship of Agriculture to Soil and Water Production. Cornell Univ. Press. p. 11-122.

Power, J.F. 1972. Fate of fertilizer nitrogen applied to a Northern Great Plains ecosystem. J. Range Manage. 25: 367-371.
Rauzi, Frank. 1978. High rates of nitrogen change composition of shortgrass rangeland in Southeastern Wyoming. J. Range Manage. 30: 366-370.

Rogler, George A., and Russell J. Lorenz. 1957. Nitrogen fertilization of Northern Great Plains rangeland. J. Range Manage. 10: 156-160.

Westin, F.C., G.J. Buntley, and B.C. Brage. 1955. Soil and weather. S. Dak. Agr. Exp. Sta. Circ. 116. Agr. Res. 6-18.

Wight, J. Ross. 1976. Range fertilization in the northern Great Plains. J. Range Manage. 29: 180-185.

\section{Practical Guides for Range Management}

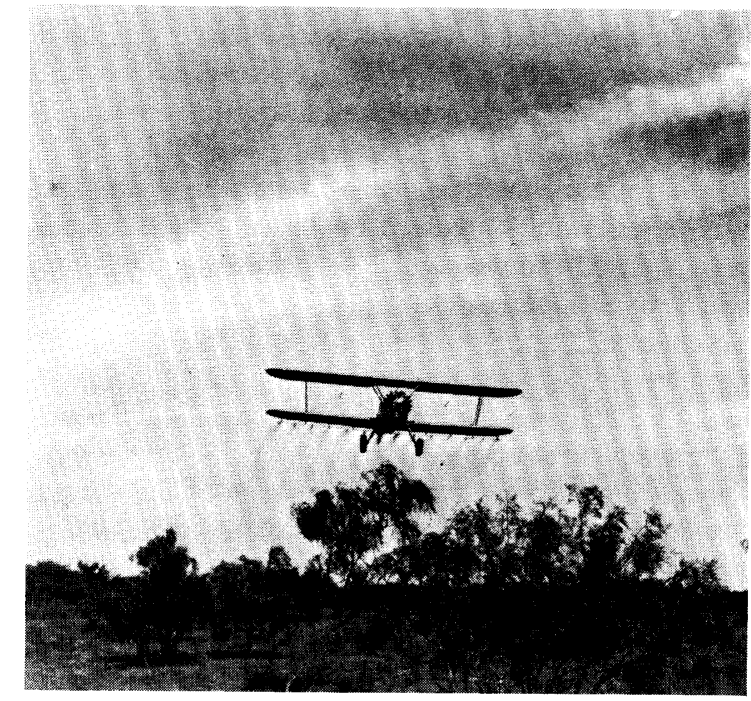

BRUSH MANAGEMENT: Principles and Practices for Texas and the Southwest

\section{By Charles J. Scifres}

A comprehensive guide to rangeland brush management, including discussion of specific brush problems and practical methods of control, the impact on the environment, and specialized control systems.

384 pp. 92 illus. $\$ 17.50$ cloth

\section{COMMON TEXAS GRASSES: An Illustrated Guide \\ By Frank W. Gould}

As a ready reference for the rancher, farmer, or amateur botanist to the 150 most familiar and important species of grasses that grow in Texas, this field guide is complete with a line drawing of each species, a botanical description in layman's terms of each species or variety, and information on distribution and growing conditions.

320 pp. 150 illus. $\$ 10.95$ cloth; $\$ 6.95$ paper

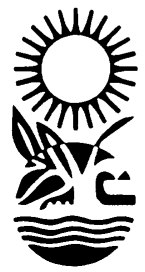

\section{Texas AdM University Press}

Drawer C, College Station, Texas 77843

Please send me the following books:

Qty.

Brush Management

Title

asses (cloth)

Common Texas Grasses (paper)

$\square$ Payment enclosed with order. Texas residents add 5\% sales tax.

$\square$ Bill my account (libraries and bookstores only).

Name

Street

City

State

Zip 